5 Mulhern LW, Friday GA, Perri JA. Arthritis complicating varicella infection. Paediatrics 1971;48:827-9.

6 Fierman AH. Varicella associated arthritis occurring before the exanthem. Clin Paediatr 1990;29:188-90.

7 Heath RB, Kangro HL, Potter CW. Varicella zoster influenza. In: Zuckerman AJ, Banatvala JE, Pattison JR, eds. Principles and practice of clinical virology. London: J Wiley and Sons, 1990:43-68.

8 Evers KG, Zippel C, Kruger J. Varicella arthritis: a rare complication of varicella. Monatsschr Kinderheilkd. 1980;128:147-52.
9 Easton AJ, Eglin RP. In situ hybridisation. In: Sawyer P, ed. Methods in gene technology. 1. London: JAI Press, 1990:185-202.

10 Jira M, Malkovsky M, Denman AM, et al. Lymphokine activated killer cell activity in rheumatoid arthritis. Clin Exp Immunol 1987;68:535-42.

11 Lavelle-Jones M, Al-Hadrani A, Spiers EM, Cambell FC, Cushieri A. Reactivation of rheumatoid arthritis during continuous infusion of interleukin 2. evidence of phocyte control of rheumatoid disease. $B M J 1990 ; 301: 97$.

\title{
Use of serum from patients with polycythaemia or haemochromatosis for laboratory external quality assurance exercises
}

\author{
J I O Craig, P L Yap, C Green, A Stewart, A Ellis, J Seth
}

\begin{abstract}
Some External Quality Assessment Schemes (EQAS) require large volumes of human serum. During a one year period, 595 units of blood were obtained from 87 patients with haemochromatosis and polycythaemia, who underwent therapeutic venesection at the Edinburgh and South East Scotland Blood Transfusion Service. Serum from $59 \%$ of these donations was used in the EQAS for peptide hormones and related substances. The cost of the serum collection was $£ 109 /$ litre, but was only $£ 33 /$ litre of serum if the cost of the actual venesection was excluded. Results from tests on the sera were satisfactory in a variety of immunoassays for several different hormones.
\end{abstract}

EQA schemes with requirements for large volumes of serum should consider therapeutic venesection as a cost effective means of obtaining serum.

In the United Kingdom several External Quality Assessment Schemes (EQAS) have been organised to assess objectively assay results from hospital laboratories, and to evaluate interlaboratory comparability with the aim of improving analytical performance and patient care. ${ }^{1}$ Human serum is required for some schemes and major difficulties are encountered in obtaining the large volumes required.

Repeated venesection of patients who have polycythaemia or haemochromatosis is part of standard management. We therefore investigated the use of serum removed during the venesection of these patients for EQAS.

\section{Methods}

All patients referred for therapeutic venesection to the Blood Transfusion Service from haematology and gastroenterology clinics at the Royal Infirmary of Edinburgh (a 1000 bed hospital) during April 1989 were included in the study. Patients with haemochromatosis underwent venesection weekly until the serum ferritin concentration reached $50 \mu \mathrm{g} / 1$ and thereafter at three to four monthly intervals as required to keep the serum ferritin concentration below this level. Patients with polycythaemia underwent venesection every one to two weeks to a target haemoglobin of $12-13 \mathrm{~g} / \mathrm{dl}$, according to their clinical condition.

Consent was obtained for use of the patient's blood or its components and for routine laboratory testing (including testing for human immunodeficiency virus antibodies and hepatitis B surface antigen). Venesection was performed by trained nursing staff at the Edinburgh and South East Scotland Blood Transfusion Service in an outpatient clinic, the blood being collected into a double blood pack unit without anticoagulants (Fenwall, Travenol Laboratories, Norfolk, England). The blood was then centrifuged and the serum separated, pooled, and stored at $-20^{\circ} \mathrm{C}$ until despatch to the laboratory organising the EQAS for peptide hormones and related substances. On receipt, aliquots were removed for determination of endogenous hormone concentrations and the remainder refrozen after the addition of sodium azide $(0 \cdot 1 \%)$. Pooled sera prepared from donations selected by hormone concentration were passed through a $0.2 \mu \mathrm{m}$ filter and dispersed in nonsterile plastic tubes. Aliquots were then refrozen at $-20^{\circ} \mathrm{C}$, pending distribution at room temperature, to laboratories by first class mail. In some EQAS pools international standards or serum with high concentrations of endogenous hormones were added to give more clinically relevant concentrations, or to assess analytical recovery or specificity.

\section{Results}

A total of 87 patients, 69 with polycythaemia and 18 with haemochromatosis (13 women, 74 men; mean age 60.4 years; range $24-84$ years 
underwent venesection) during the study period. Five hundred and ninety five venesections of $100-500 \mathrm{ml}$ (mean $304 \mathrm{ml}$ ) were performed, 127 from patients with haemochromatosis (mean $7 \cdot 1$ venesections a patient) and 468 from those with polycythaemia (mean 6.8 a patient). The serum derived from $59 \%$ of those donations (34 litres) was used in the United Kingdom EQAS for peptide hormones and related substances in which 310 laboratories are registered for the analysis of up to 10 different analytes. The ranges of concentrations of endogenous hormones are shown in table 1.

The total cost for obtaining 34 litres of serum for EQAS was $£ 3713$ or $£ 109 /$ litre (table 2). If the cost of the venesection procedure was not taken into account, the cost was $£ 1119$ or $£ 33 /$ litre.

The suitability of serum from these patients is supported by the observation that in most EQAS the observed all-laboratory consensus mean agrees with the calculated value on adding standard hormone, and that there is a linear correlation between hormone concentration and dilution factor on mixing sera containing high and low concentrations.

\section{Discussion}

The key ethical issue in the approach we have described is that pressure to bleed patients to obtain an adequate supply of material may enter into the consideration of whether it is clinically appropriate to perform venesection. We addressed this concern by ensuring that the referring physicians are the trigger to start and stop venesection and that the locally agreed guidelines for venesection are followed rigorously. The patients continue to be super-

Table 1 Endogenous hormone concentrations in units of blood taken from patients with haemochromatosis and polycythaemia

\begin{tabular}{ll}
\hline Hormone & Concentration range \\
\hline Follicle stimulating hormone & $2-100 \mathrm{U} / 1$ \\
Luteinising hormone & $2-50 \mathrm{U} / 1$ \\
Prolactin & $50-700 \mathrm{mU} / 1$ \\
Growth hormone & up to $5 \mathrm{mU} / 1$ \\
CEA & up to $150 \mathrm{U} / 1$ \\
\hline
\end{tabular}

Table 2 Cost of therapeutic venesection and preparation of serum

\begin{tabular}{|c|c|c|}
\hline & $\begin{array}{l}\text { Cost }^{\star} / \\
\text { donation } \dagger\end{array}$ & $\begin{array}{l}\text { Total cost } \\
\text { donation } \dagger\end{array}$ \\
\hline $\begin{array}{l}\text { Blood Transfusion Service: } \\
\text { Venesection pack } \\
\text { Staff-RGN }\end{array}$ & 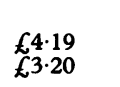 & $£ 7 \cdot 39$ \\
\hline $\begin{array}{l}\text { Virology testing: } \\
\text { Consumables } \\
\text { Staff }\end{array}$ & $\begin{array}{l}£ 1 \cdot 00 \\
£ 0.89\end{array}$ & $£ 1.89$ \\
\hline $\begin{array}{l}\text { Separation of serum, pooling } \\
\text { and storage: } \\
\text { Consumables } \\
\text { Staff }\end{array}$ & $\begin{array}{l}£ 0.40 \\
£ 0.90\end{array}$ & $£ 1 \cdot 30$ \\
\hline
\end{tabular}

vised and managed at their original clinics throughout the venesection course. These measures allow venesection to be performed as a prescriptive service. Additionally, the supervising clinician and the staff in the Blood Transfusion Service who perform the venesection are managed separately from those involved in obtaining the serum. Thus the clinical management of patients is not influenced in any way by the need to supply serum.

Over the years, the number of EQAS and participants has increased with the consequent increased need for EQAS samples that resemble patient samples in all respects. Recalcified plasma is less suitable because plasma proteins precipitate when stored. Human serum is not easily obtained and we were unable to find a satisfactory commercial source for the large volumes of serum required; blood from therapeutic venesection would automatically be discarded, if no other use could be found for it.

A key question is whether serum from this source satisfactorily mimics the behaviour of normal serum in the variety of immunoassay methods used by EQAS participants. There is no reason to suspect gross abnormalities in the serum matrix, as serum proteins are normal in these patients. Previous reports have detailed the results in the growth hormone, ${ }^{2} \alpha$ fetoprotein ${ }^{3}$, follicle stimulating hormone and luteinising hormone ${ }^{4}$ and prolactin ${ }^{5}$ EQAS. Although satisfactory performance in all methods is difficult to show conclusively, the behaviour of the serum in recovery and dilution experiments is satisfactory, providing evidence of its suitability.

We suggest that other EQA schemes with a need for large amounts of human serum should consider adopting our approach in collaboration with their local haematologists and gastroenterologists and Blood Transfusion Service, as many patients with haemochromatosis or polycythaemia are available and the material is suitable for use in a wide range of assays.

We thank Dr Karen Bell for helpful discussion, Mr David Ross for technical assistance, Sandra Gray for help with data collection and the consultant haematologists and gastroenterologists at the Royal Infirmary of Edinburgh for referring patients for venesection.

1 Whitehead TP, Woodford FP. External quality assessment of clinical laboratories in the United Kingdom. J Clin Pathol 1981;34:947-57.

2 Seth J, Hanning I, Bacon RRA, Hunter WM. Quality of performance of assays for serum growth hormone in the quality assessment scheme. Clin Chim Acta 1988;174: 171-84.

3 Seth J, Hanning I, Bacon RRA, Hunter WM. Quality of performance of assays for maternal serum alphafetoprotein in the United Kingdom: evidence from the UK external quality assessment scheme 1980-1987. Ann Clin Biochem 1988;25:310-8.

J, Hanning I, Bacon RRA, Hunter WM. Progress and problems in immunoassays for serum pituitary gonadotropins: evidence from the UK external quality assessment scheme, (EQAS) 1980-89. Clin Chim Acta 1989; 186:67-82.

5 Hanning I, Seth J, Bacon RRA, Hunter WM, Al-Sadie R. Progress in immunoassays for serum prolactin: evidence from the UK external quality assessment scheme (EQAS) 1980-89. Ann Clin Biochem 1991;28:91-7. 